7. Romaniuk, S. A. (2013). Rozvytok rehioniv u vidkrytii ekonomitsi: teoriia, polityka, praktyka: monohrafiia [Development of regions in open economy: theory, policy, practice: monograph]. Kyiv: NADU [in Ukrainian].

8. Semynozhenko, V. P. \& Danylyshyn, B. M. (2005). Novyi rehionalizm [New regionalism]. Kyiv: Naukova dumka [in Ukrainian].

9. Tulchynskyi, R. V. (2018). Determinanty stanovlennia novoho rehionalizmu: teoriia, metodolohiia, praktyka [Determinants of the emergence of a new regionalism: theory, methodology, practice]. Kherson: PP Vyshemyrskyi V.S. [in Ukrainian].

10. Kuibida, S. V. (2017). Formuvannia ta realizatsiia novoi rehionalnoi polityky v Ukraini [Formation and implementation of new regional policy in Ukraine]. Efektyvnist derzhavnoho upravlinnia - Public administration efficiency, 1(50), 13-20 [in Ukrainian].

11. Rehionalnyi rozvytok ta derzhavna rehionalna polityka $v$ Ukraini: stan i perspektyvy zmin u konteksti hlobalnykh vyklykiv ta yevropeiskykh standartiv polityky: analit. zvit [Regional development and national regional policy in Ukraine: the state and prospects of change in the context of global challenges and European policy standards: an analyst. report] / Proekt YeS «Pidtrymka polityky rehionalnoho rozvytku v Ukraini» - EU project "Support to regional development policy in Ukraine". Kyiv. Retrieved from http://surdp.eu/uploads/files/Analytical_Report_Main_part_UA.pdf [in Ukrainian].

12. Chertkov, S. I. (2013). Transformatsiia paradyhmy rehionalnoho rozvytku v umovakh hlobalizatsii [Transformation of the paradigm of regional development in the conditions of globalization]. Nauka y ekonomika - Science and economics. 4/ 2, 366-371 [in Ukrainian].

13. Regional Development Policies in OECD Countries (2010). Retrieved from http://www.planejamento.gov.br/secretarias/upload /Arquivos/seges/arquivos/OCDE2011/OECD_Regional_Countries.pdf

14. Keating, M. (1998). Is There a Regional Level of Government in Europe? Regions in Europe / Edited by P. le Galèsand and C. Lequesne. London: Routledge, 11-29.

15. Rehionalna polityka v krainakh Yevropy. Uroky dlia Ukrainy [Regional policy in European countries. Lessons for Ukraine]. Kyiv: Lohos [in Ukrainian].

16. Melnyk, M. I., ed. (2014). Metropolizatsiini protsesy v rehioni: kontseptualni pidkhody ta prykladni aspekty prostorovoho analizu: naukovo-analitychna dopovid [Metropolisation processes in the region: conceptual approaches and applied aspects of spatial analysis: scientific-analytical report]. Lviv: Instytut rehionalnykh doslidzhen NAN Ukrainy [in Ukrainian]

17. Romaniuk, S. A. (2016). Rehionalnyi rozvytok i detsentralizatsiia: teoretychni ta praktychni aspekty [Regional development and decentralization: theoretical and practical aspects]. Rehionalna ekonomika - Regional economy, 3, 10-18 [in Ukrainian].

18. Neysbit, Dzh. (2003). Megatrendy [Megatrends]. Moskva: AST. Ermak [in Russian].

19. Zhalilo, Ya. A. (2017). Nova rehionalna polityka dlia novoi Ukrainy: analit. dop. [New Regional Policy for a New Ukraine: An Analyte. ext.]. Kyiv: Instytut suspilno-ekonomichnykh doslidzhen [in Ukrainian]

20. Elkanov, R. Kh. (2012). Polyusa razvitiya i tochki rosta innovatsionnoy ekonomiki: rossiyskiy i zarubezhnyy opyt [Poles of development and growth points of the innovation economy: Russian and foreign experience]. Sovremennaya nauka: aktualnyye problemy teorii i praktiki - Modern science: actual problems of theory and practice. № 2. Retrieved from http://www.vipstd.ru/nauteh/index.php/---ep12-02/388-a [in Russian].

21. Leonov, S. N. \& Sidorenko, O. V. (2011). Zakonomernosti i osobennosti realizatsii selektivnoy regionalnoy politiki [Patterns and features of the implementation of selective regional policy]. Prostranstvennaya ekonomika - Spatial Economics, 1, 67-80 [in Russian]. 22. Holubiak, N. R. (2013). Kontseptualni osnovy analizu rehionalnoi polityky: politychnyi vymir [Conceptual foundations of regional policy analysis: a political dimension]. Prykarpatskyi visnyk NTSh. Dumka - Precarpathian Bulletin of NTSh. Opinion, 3, 71-78 [in Ukrainian].

УДК 377.44:631.1.027

Шубалий О. М., д.е.н., професор

Косінський П.М., аспірант

Луцький національний технічний університет

\title{
ОЦІНКА ЕФЕКТИВНОСТІ ВИКОРИСТАННЯ ПЕРСОНАЛУ У СФЕРІ СІЛЬСЬКОГО ГОСПОДАРСТВА РЕГІОНУ
}

У статті проведено оцінку ефективності використання персоналу у сфері сільського господарства у Волинській області.

Ключові слова: персонал, оцінка, ефективність, сільське господарство, регіон.

Шубалый А.М., Косинський П.Н.

\section{ОЦЕНКА ЭФФЕКТИВНОСТИ ИСПОЛЬЗОВАНИЯ ПЕРСОНАЛА В СФЕРЕ СЕЛЬСКОГО ХОЗЯЙСТВА РЕГИОНА}

В статье проведена оценка эффективности использования персонала в сфере сельского хозяйства в Волынской области.

Ключевые слова: персонал, оценка, эффективность, сельское хозяйство, регион.

Shubalyi O.M., Kosinskyi P.M. 


\section{ASSESSMENT OF THE EFFICIENCY OF THE USE OF THE STAFF IN THE AGRICULTURAL AREA}

The article assesses the effectiveness of staff use in agriculture in the Volyn region.

Keywords: staff, evaluation, efficiency, agriculture, region.

Постановка проблеми у загальному вигляді та іï зв'язок з важливими науковими чи практичними завданнями. Забезпечення ефективності використання персоналу в теперішніх складних умовах розвитку національної економіки потребує проведення критичного аналізу стану, тенденцій розвитку та потенційних можливостей реалізації нових підходів до організації цього процесу на різних рівнях управління. Особливо актуальним $є$ дослідження цих питань на прикладі сфери сільського господарства, господарські суб'єкти якої динамічно розвиваються та мають значні резерви для подальшого росту. В таких умовах виникає необхідність зосередження уваги на вивченні особливостей та перспектив підвищення ефективності використання персоналу у сфері сільського господарства на регіональному рівні відповідно до галузевої специфіки та регіональних особливостей.

Аналіз останніх досліджень, у яких започатковано вирішення проблеми. Актуальні проблеми, які прямо чи опосередковано пов'язані із забезпечення ефективності використання персоналу на вітчизняних підприємствах активно досліджували відомі вітчизняні вчені: Балабанова Л. В., Сардак. О. В., Башук Г. О., Вітюнін В.О., Грішнова О. А., Демиденко Л.М., Кибанов А. Я., Корягіна А.Д., Крушельницька О. В, Мельничук Д. П., Данюк В.М., Петюх В. М., Цимбалюк С. О., Мінчак Н.Д., Мочерний С.В., Никифоренко В. Г., Олексенко Т., Петрова І.Л., Петюх В. М., Писаревська Г.І., Прокопенко М.В., Сівашенко І. О., Шахно А.Ю., Буханець В.В., Скочко К.П. та багато ін. [3-7]. Враховуючи прискорений розвиток сфери сільського господарства, яка активно розвивається протягом останніх декількох років, виникає багато проблемних питань, що стосуються забезпечення ефективності використання персоналу та забезпечення його розвитку.

Цілі статті. Мета дослідження полягає в проведенні аналізу та оцінки ефективності використання персоналу у сфері сільського господарства Волинської області.

Виклад основного матеріалу дослідження 3 повним обгрунтуванням отриманих наукових результатів. Сфера сільського господарства відноситься до провідних ланок господарського комплексу Волинської області. Поряд 3 показниками виробництва і реалізації продукції також важливе значення має вивчення зміни основних показників ефективності використання персоналу у сфері сільського господарства регіону (табл. 1).

Таблиця 1.

Зміна основних показників ефективності використання персоналу у сфері сільського господарства Волинської області за 2013-2017 рр. (осіб)

\begin{tabular}{|l|r|r|r|r|r|r|r|r|}
\hline \multicolumn{1}{|c|}{ Чисельність } & \multicolumn{3}{|c|}{ Роки } & \multicolumn{2}{|c|}{ Відносн. відх., \% } \\
\cline { 2 - 9 } & 2013 & 2014 & 2015 & 2016 & 2017 & $\begin{array}{c}2017 / \\
2016\end{array}$ & $\begin{array}{r}2016 / \\
2015\end{array}$ & $\begin{array}{c}2017 / \\
2013\end{array}$ \\
\hline $\begin{array}{l}\text { Середньооблікова кількість штатних працівників, } \\
\text { осіб }\end{array}$ & 6478 & 7854 & 6164 & 5734 & 5112 & $-10,8$ & $-7,0$ & $-21,1$ \\
\hline $\begin{array}{l}\text { Відпрацьовано в середньому одним штатним } \\
\text { працівником, год }\end{array}$ & 1697 & 1677 & 1750 & 1778 & 1764 & $-0,8$ & 1,6 & 3,9 \\
\hline $\begin{array}{l}\text { Використання фонду робочого часу штатних } \\
\text { працівників (відпрацьовано у \% до табельного } \\
\text { фонду робочого часу) }\end{array}$ & 84,8 & 83,8 & 87,7 & 88,8 & 89,2 & 0,5 & 1,3 & 5,2 \\
\hline $\begin{array}{l}\text { Середньомісячна номінальна заробітна плата } \\
\text { штатних працівників, грн }\end{array}$ & 1816 & 2060 & 2810 & 3456 & 5318 & 53,9 & 23,0 & 192,8 \\
\hline $\begin{array}{l}\text { Обсяг виробництва продукціі (у цінах 2010 року) у } \\
\text { розрахунку на 1 штатного працівника, тис. грн }\end{array}$ & 979,5 & 858,7 & 1043,9 & 1143,8 & 1344,3 & 17,5 & 9,6 & 37,3 \\
\hline
\end{tabular}


Продовження таблиці 1

\begin{tabular}{|l|r|r|r|r|r|r|r|r|}
\hline \multicolumn{1}{|c|}{1} & \multicolumn{1}{c|}{2} & \multicolumn{1}{c|}{3} & \multicolumn{1}{c|}{4} & \multicolumn{1}{c|}{5} & \multicolumn{1}{c|}{7} & \multicolumn{1}{c|}{8} & 9 \\
\hline $\begin{array}{l}\text { Обсяг виробництва продукції (у цінах 2010 року) у } \\
\text { розрахунку на 1 грн витрат на оплату праці, грн. }\end{array}$ & 44,94 & 34,75 & 30,96 & 27,58 & 21,06 & $-23,6$ & $-10,9$ & $-53,1$ \\
\hline $\begin{array}{l}\text { Капільні інвестиції у розрахунку на 1 штатного } \\
\text { працівника, тис грн / особу }\end{array}$ & 37,5 & 36,3 & 128,5 & 128,9 & 217,0 & 68,4 & 0,3 & 479,1 \\
\hline $\begin{array}{l}\text { Рентабельність персоналу (чистий прибуток у } \\
\text { розрахунку на 1 штатного працівника, тис грн }\end{array}$ & 31,6 & 35,3 & 157,8 & 172,1 & 294,8 & 71,3 & 9,0 & 833,8 \\
\hline Коефіціснт плинності кадрів, \% & 44,0 & 43,7 & 47,2 & 45,2 & 46,1 & 2,2 & $-4,3$ & 4,8 \\
\hline
\end{tabular}

Примітка. Побудовано за даними [1-2; 8-10].

Зменшення кількості працівників зумовило збільшення обсягів виробництва одним працівником. За період 2013-2017 рр. обсяг виробництва продукції у розрахунку на одного штатного працівника зріс на $37,3 \%$.

Негативною тенденцію є зменшення обсягів виробництва продукції на 1 грн витрат на оплату праці (за період 2013-2017 рр. майже вдвічі). Збільшення кількості капітальних інвестицій у розрахунку на одного штатного працівника $є$ позитивною тенденцією, адже вкладаються кошти у розвиток сільськогосподарських підприємств (в покращення умов праці, оновлення техніко-технологічної бази тощо). В останні роки даний показник суттєво збільшився: якщо в 2013 році він становив 128,5 тис. грн/особу, то в 2016 році зріс на 0,3\%, а в 2017 році збільшився аж на 68,4\%, що на 479,1\% більше, ніж в 2013 році.

Надалі доцільно провести порівняння динаміки середньомісячної заробітної плати у сільському господарстві із загальним рівнем по Волинській області загалом за 20102017 pp. (рис. 1).

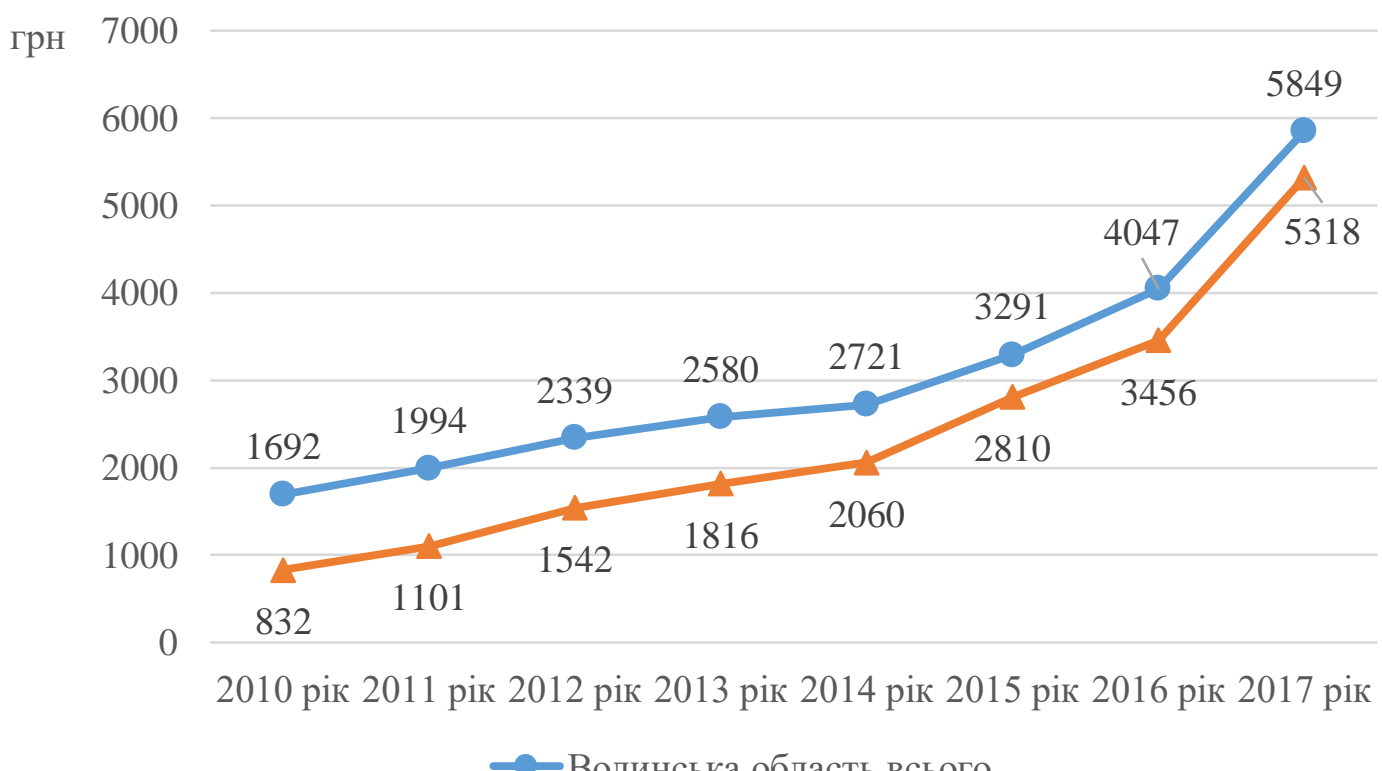

Рис. 1. Порівняння динаміки середньомісячної заробітної плати у сільському господарстві із загальним рівнем по Волинській області загалом за 2010-2017 pp. (побудовано за даними [1-2; 8-10])

3 рисунку 1 видно, що впродовж 2010-2017 рр. середньомісячна зарплата одного працівника у сфері сільського господарства зростала. Якщо в 2010 році середня заробітна плата одного працівника сільськогосподарського підприємства була меншою за середню заробітну плату в області майже вдвічі, то в 2012 році вона становила 1542 грн, що на $51,6 \%$ менше середньої зарплати в області. А в 2014 році середня зарплата 
сільгосппрацівника була нижчою за середню зарплату в області на $32,1 \%$.

32014 року середня заробітна плата працівника сільського господарства у Волинській області стала щорічно зростати швидкими темпами. Якщо в 2016 році вона становила 3456 грн, то в 2017 вона зросла на 53,9\% і склала 5318 грн, що на 10\% менше, ніж середня заробітна плата в області.

Дана ситуація є сприятливою для працівників, задіяних у сільському господарстві й свідчить про розвиток сільського господарства в області і здатність його конкурувати з провідними галузями промисловості області.

Поряд 3 цим важливо провести порівняння індексів зростання продукції та середньомісячної номінальної заробітної плати у сільському господарстві у Волинській області за 2012-2017 рр. (рис. 2).

Згідно рисунку 2 зміни індексів сільськогосподарської продукції і середньомісячної заробітної плати штатних працівників за аналізований період $\epsilon$ динамічними. Зміну індексу сільгосппродукції можна пояснити змінами обсягів виробництва продукції сільського господарства, спричинених зміною урожайності даної продукції. Загалом даний показник був більш менш стабільним і коливався в межах $100,0-120,0 \%$.

Більш динамічною була зміна індексу середньомісячної заробітної плати штатних працівників. У 2017 році даний показник перевищив аналогічний показник 2012 року на $13,8 \%$. Але найбільш динамічною була зміна коефіцієнта випередження реалізації продукції до індексу зміни заробітної плати. Впродовж аналізованого періоду даний показник коливався в межах 0,72-1,05.

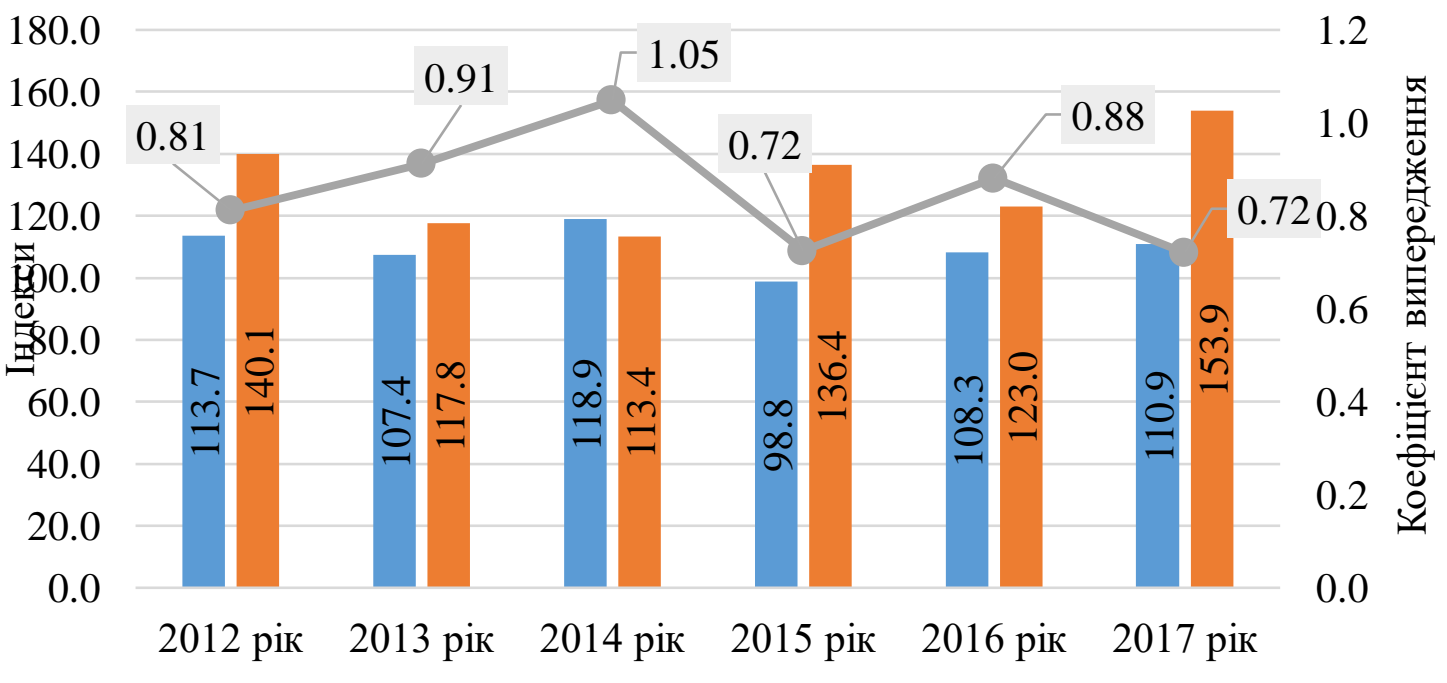

І Індекс сільськогосподарської продукції, \% до попереднього року

—— Індекс середньомісячної номінальної заробітної плати штатних працівників, \% до попереднього року

- Коефіцієнт випередження індексу реалізації продукції до індексу зміни заробітної плати

Рис. 2. Порівняння індексів зростання продукції та середньомісячної номінальної заробітної плати у сільському господарстві у Волинській області за 2012-2017 рр. (побудовано за даними [1-2; 8-10])

На наступному етапі проведено аналіз ефективності використання фонду оплати штатних працівників промисловості Волинської області за 2012-2017 рр. (табл. 2). 
Таблиця 2.

Аналіз ефективності використання фонду оплати штатних працівників промисловості Волинської області за 2012-2017 pр.

\begin{tabular}{|l|c|c|c|c|c|c|}
\hline \multicolumn{1}{|c|}{ Показники } & 2012 рік & 2013 рік & 2014 рік & 2015 рік & 2016 рік & 2017 рік \\
\hline $\begin{array}{l}\text { Середньооблікова кількість штатних } \\
\text { працівників, осіб }\end{array}$ & 8571 & 6478 & 7854 & 6164 & 5734 & 5112 \\
\hline $\begin{array}{l}\text { Обсяг реалізованої } \\
\text { сільськогосподарської продукції } \\
\text { (товарів, послуг), млн. грн. }\end{array}$ & 2257,8 & 2428,4 & 3157,2 & 5511,9 & 6381,8 & 8478,9 \\
\hline $\begin{array}{l}\text { Обсяг реалізації продукції у } \\
\text { розрахунку на 1 штатного працівника, } \\
\text { тис. грн }\end{array}$ & 263,4 & 374,9 & 402,0 & 894,2 & 1113,0 & 1658,6 \\
\hline Фонд оплати праці, млн. грн. & 155,1 & 141,2 & 194,1 & 207,8 & 237,8 & 326,3 \\
\hline $\begin{array}{l}\text { Суму доходу від реалізації продукції } \\
\text { на одну гривню зарплати, грн }\end{array}$ & 14,56 & 17,20 & 16,27 & 26,53 & 26,84 & 25,98 \\
\hline $\begin{array}{l}\text { Темп росту обсягу реалізованої } \\
\text { промислової продукції (товарів, } \\
\text { послуг) у розрахунку на 1 штатного } \\
\text { працівника, \% }\end{array}$ & 149,1 & 142,3 & 107,2 & 222,4 & 124,5 & 149,0 \\
\hline $\begin{array}{l}\text { Темп росту середньомісячної } \\
\text { заробітної плати штатного працівника, } \\
\text { \% }\end{array}$ & 140,1 & 117,8 & 113,4 & 136,4 & 123,0 & 153,9 \\
\hline $\begin{array}{l}\text { Коефіціснт випередження росту обсягу } \\
\text { реалізації до росту зарплати }\end{array}$ & 1,06 & 1,21 & 0,95 & 1,63 & 1,01 & 0,97 \\
\hline $\begin{array}{l}\text { Сума економії (+) або перевитрати (-) } \\
\text { фонду оплати праці, млн. грн }\end{array}$ & 8,7 & 32,3 & $-7,7$ & 122,4 & 2,5 & $-7,5$ \\
\hline
\end{tabular}

Примітка. Побудовано за даними [1-2; 8-10].

Як видно з даних таблиці 2, впродовж 2012-2017 pp. фонд оплати праці постійно зростав і в 2017 році склав 326,3 млн грн, що перевищує показники 2012 року вдвічі. Зменшення кількості працівників і збільшення фонду оплати праці вплинуло на збільшення розміру середньої заробітної плати працівників сільськогосподарської сфери Волинської області.

Надалі проведено аналіз укладення колективних договорів у сільському господарстві Волинської області за 2013-2017 рр. (табл. 3).

Таблиця 3. Аналіз укладення колективних договорів у сільському господарстві Волинської області за 2013-2017 pp.

\begin{tabular}{|c|c|c|c|c|c|c|c|c|c|}
\hline \multirow[b]{2}{*}{$\begin{array}{c}\text { Види економічної } \\
\text { діяльності }\end{array}$} & \multicolumn{5}{|c|}{ Роки } & \multicolumn{4}{|c|}{ Віднос. відх., \% } \\
\hline & 2013 & 2014 & 2015 & 2016 & 2017 & \begin{tabular}{|l|}
$2016 /$ \\
2015
\end{tabular} & $\begin{array}{l}2015 / \\
2014\end{array}$ & $\begin{array}{l}2014 / \\
2013\end{array}$ & $\begin{array}{l}2016 / \\
2012\end{array}$ \\
\hline \multicolumn{10}{|c|}{ Кількість укладених та зареєстрованих колективних договорів, одиниць } \\
\hline Всього & 2476 & 2550 & 2101 & 2171 & 2058 & $-5,2$ & 3,3 & $-17,6$ & $-16,9$ \\
\hline $\begin{array}{l}\text { Сільське господарство, } \\
\text { лісове господарство та } \\
\text { рибне господарство }\end{array}$ & 127 & 147 & 114 & 130 & 99 & $-23,8$ & 14,0 & $-22,4$ & $-22,0$ \\
\hline сільське господарство & 103 & 126 & 93 & 107 & 76 & $-29,0$ & 15,1 & $-26,2$ & $-26,2$ \\
\hline \multicolumn{10}{|c|}{ Кількість працівників, охоплених колективними договорами, осіб } \\
\hline Всього & 166427 & 168812 & 153249 & 153718 & 150166 & $-2,3$ & 0,3 & $-9,2$ & $-9,8$ \\
\hline $\begin{array}{l}\text { Сільське господарство, } \\
\text { лісове господарство та } \\
\text { рибне господарство }\end{array}$ & 8289 & 9172 & 8579 & 8483 & 8057 & $-5,0$ & $-1,1$ & $-6,5$ & $-2,8$ \\
\hline сільське господарство & 5990 & 6438 & 5434 & 5072 & 4422 & $-12,8$ & $-6,7$ & $-15,6$ & $-26,2$ \\
\hline
\end{tabular}


Продовження таблиці 3

Кількість працівників, охоплених колективними договорами, у \% до облікової кількості штатних працівників

\begin{tabular}{|l|r|r|r|r|r|r|r|r|c|}
\hline Всього & 86,4 & 86,9 & 83,9 & 83,9 & 80,8 & $-3,7$ & 0,0 & $-3,5$ & $-6,5$ \\
\hline $\begin{array}{l}\text { Сільське господарство, } \\
\text { лісове господарство та } \\
\text { рибне господарство }\end{array}$ & 97,3 & 91,6 & 91,4 & 96,5 & 92,2 & $-4,5$ & 5,6 & $-0,2$ & $-5,2$ \\
\hline сільське господарство & 96,3 & 88,5 & 87,1 & 94,5 & 86,9 & $-8,0$ & 8,5 & $-1,6$ & $-9,8$ \\
\hline
\end{tabular}

Примітка. Побудовано за даними [1-2; 8-10].

Впродовж 2013-2017 pp. у Волинській області спостерігаються тенденції до зменшення кількості укладених та зареєстрованих колективних договорів, зменшення кількості працівників охоплених колективними договорами.

3 них, за аналізований період, в сільському господарстві області кількість колективних договорів зменшилась на 26,2\%. Найбільші темпи зменшення укладання колективних договорів та працівників охоплених ними припали на 2017 рік, коли обсяги даних показників знизились на 29,0\% і 12,8\% відповідно. Таким чином, кількість працівників, охоплених колективними договорами, у відношенні до облікової кількості штатних працівників у сільському господарстві становила в 2017 році 86,9\%.

На завершальному етапі вивчено динаміку кількості працівників, охоплених колективними договорами у сільському господарстві Волинської області за 20132017pр. (рис. 3).

Як видно з рисунку, в 2014 році спостерігається незначне зростання кількості працівників охоплених колективним договором у порівнянні з попереднім роком. Однак у відношенні до облікової кількості штатних працівників, кількість працівників охоплених колективним договором зменшилась на 5,9\%.

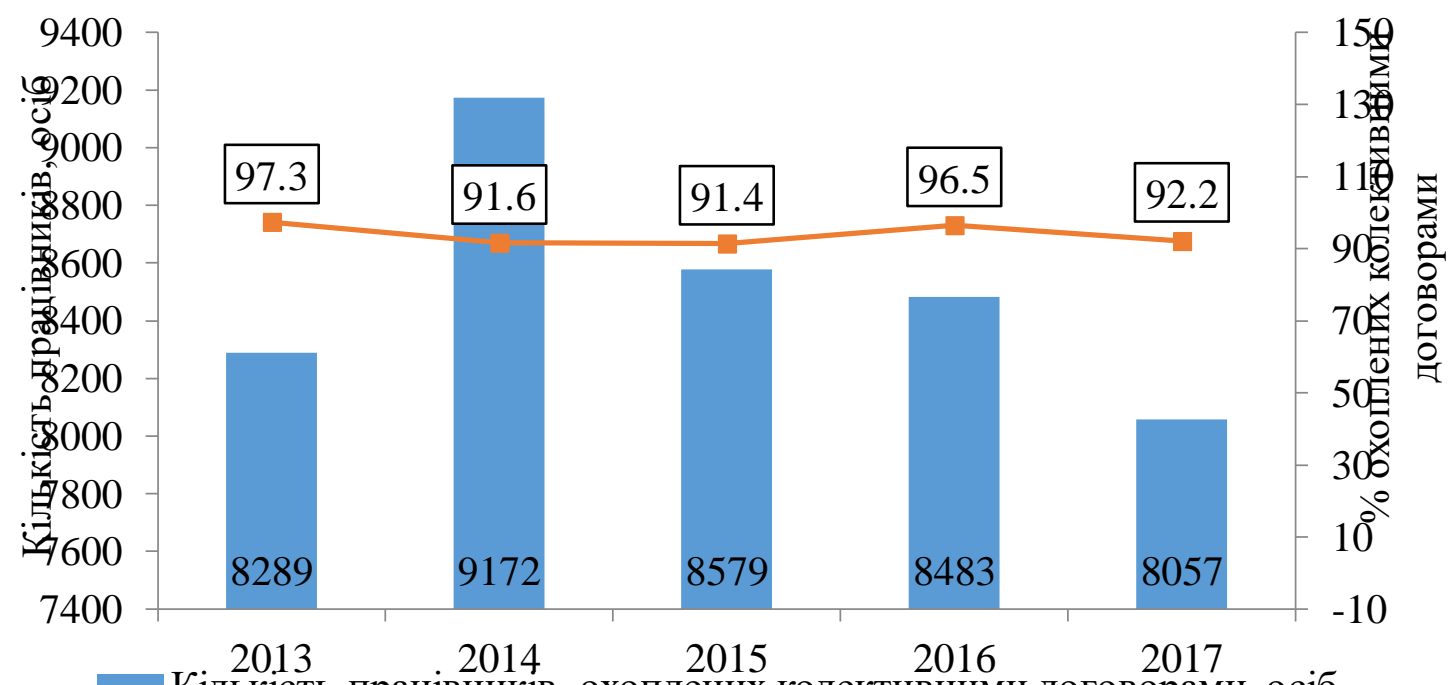

Кількість працівників, охоплених колективними договорами, осіб

-—-Кількість працівників, охоплених колективними договорами, у \% до облікової кількості штатних працівників

Рис. 3. Динаміка кількості працівників, охоплених колективними договорами у сільському господарстві Волинської області за 2013-2017 рр. (побудовано за даними [1$2 ; 8-10])$

32015 року спостерігається тенденція до зменшення вище зазначених показників. 
Станом на 2017 рік кількість осіб, охоплених колективним договором у Волинській області зменшилась на 232 осіб, а у відношенні до облікової кількості штатних працівників даний показник зменшився на 5,1\% у порівнянні з 2012 роком.

Висновки. За підсумками проведеного дослідження можна зробити ряд висновків щодо ефективності використання персоналу у сфері сільського господарства регіону.

Внаслідок скорочення середньооблікової кількості штатних працівників в сільському господарстві впродовж 2013-2017 pp., показник середньої кількості годин відпрацьованих одним працівником зростав (з 1697 год у 2013 році до 1764 год у 2017 році). Скорочення кількості штатних працівників призвело до збільшення середньомісячної номінальної заробітної плати штатних працівників сільськогосподарських підприємств.

Зростання рентабельності персоналу у розрахунку на одного штатного працівника за аналізований період у 8 разів є досить сприятливим явищем, адже свідчить про ефективність вкладених інвестицій у сільськогосподарські підприємства, їх розвиток. Негативною тенденцією є збільшення коефіцієнта плинності кадрів, що свідчить про швидкий оборот кадрів на сільськогосподарських підприємствах.

Зростання суми доходу від продукції на 1 грн зарплати, стабільні темпи росту обсягу реалізованої промислової продукції у розрахунку на одного штатного працівника, зростання темпів росту середньомісячної заробітної плати одного штатного працівника вказує на ефективність використання фонду оплати штатних працівників сільського господарства Волинської області впродовж 2012-2017pp.

Отже, питання підвищення ефективності використання персоналу є важливим для забезпечення ефективності функціонування сфери сільського господарства регіону в довгостроковій перспективі. Але важливо, щоб ефективність використання персоналу забезпечувалося не за рахунок оптимізації чисельності працівників у сільському господарстві, а за рахунок розширення напрямів економічної діяльності, що дозволить паралельно вирішувати проблему підвищення добробуту населення сільських територій. Зокрема значні резерви щодо зростання зайнятості та ефективності використання персоналу існують у сфері тваринництва, яка потребує додаткової підтримки з боку держави, а також залучення додаткових інвестицій для розвитку потужних тваринницьких комплексів. В цьому контексті певний позитивний імпульс до підвищення ефективності використання персоналу у сфері сільського господарства для аграрних регіонів, зокрема Волинської області, може мати проведення земельної реформи та вдосконалення трудового законодавства.

\section{Список бібліографічного опису:}

1.Волинь-2017: статистичний щорічник / За ред. В.Ю. Науменка. Луцьк: Головне управління статистики у Волинській області, 2018. - $458 \mathrm{c.}$

2.Головне управління статистики у Волинській області: офіційний веб-сайт. Режим доступу: http://www.lutsk.ukrstat.gov.ua.

3.Демиденко Л.М. Логістичний підхід до підвищення ефективності використання персоналу аграрних підприємств. Технологічний аудит та резерви виробництва. 2012. № 1. С. 35-38.

4.Дідур К.М. Шляхи підвищення ефективності системи управління персоналом в аграрних підприємствах. Вісник Дніпропетровського державного аграрно-економічного університету. 2015. № 1 (35). С. 125-129.

5.Департамент агропромислового розвитку Волинської обласної державної адміністрації: офіційний веб-сайт. URL: http://agrovolyn.gov.ua.

6.Петришин Л. П. Удосконалення процесів формування і використання персоналу сільськогосподарських підприємств як чинника їхньої економічної поведінки. Науковий вісник Ужгородського начіонального університету. Серія: Міжнародні економічні відносини та світове господарство. 2017. Вип. 16(2). С. 65-68.

7.Посилаєва К.І., Чернякова В.О. Методичні підходи оцінки ефективності використання персоналу у сільськогосподарських підприємствах. Науковий вісник Львівського національного університету ветеринарної медицини та біотехнологій ім. Гжицького. 2010. Т. 12, № 3(5). С. 240-244.

8.Праия Волині-2015: статистичний збірник / За ред. В.О. Грабаровської. Луцьк: Головне управління статистики у Волинській області, 2016. 116 с.

9.Праия Волині-2016: статистичний збірник / За ред. В.О. Грабаровської. Луцьк: Головне управління статистики у Волинській області, 2017. 103 с. 
10. Праия Волині-2017: статистичний збірник / за ред. В.О. Грабаровської. Луцьк: Головне управління статистики у Волинській області, 2018. 117 с.

\section{Reference:}

1. Naumenko V.Yu. (2018). Volyn-2017: statystychnyi shchorichnyk [Volyn-2017: Statistical Yearbook]. Lutsk: Main Department of Statistics in the Volyn region. [in Ukrainian].

2. Holovne upravlinnya statystyky u Volyns'kiy oblasti: ofitsiynyy veb-sayt [Main Department of Statistics in the Volyn region. Official website]. Retrieved from http://www.lutsk.ukrstat.gov.ua. [in Ukrainian].

3. Demidenko L.M. (2012). Lohistychnyy pidkhid do pidvyshchennya efektyvnosti vykorystannya personalu ahrarnykh pidpryyemstv [Logistic approach to increase the efficiency of utilization of agricultural enterprises personnel]. Tekhnolohichnyy audyt ta rezervy vyrobnytstva - Technological audit and production reserves, 1, 35-38. [in Ukrainian].

4. Didur K.M. (2015). Shlyakhy pidvyshchennya efektyvnosti systemy upravlinnya personalom v ahrarnykh pidpryyemstvakh [Ways to improve the efficiency of personnel management system in agricultural enterprises]. Visnyk Dnipropetrovs'koho derzhavnoho ahrarno-ekonomichnoho universytetu - Bulletin of Dnipropetrovsk State Agrarian and Economic University, 1(35), 125-129. [in Ukrainian].

5. Departament ahropromyslovoho rozvytku Volyns'koyi oblasnoyi derzhavnoyi administratsiyi: ofitsiynyy veb-sayt. [Department of Agroindustrial Development of Volyn Regional State Administration. Official website]. Retrieved from http://agrovolyn.gov.ua. [in Ukrainian].

6. Petryshyn L.P. (2017). [Improvement of processes of formation and use of personnel of agricultural enterprises as a factor of their economic behavior]. Scientific Bulletin of Uzhgorod National University. Series: International Economic Relations and the World Economy, 16 (2), 65-68. [in Ukrainian].

7. Sender K.I., Chernyakova V.A. (2010). [Methodical approaches to assessing the efficiency of staff use in agricultural enterprises]. Scientific Bulletin of Lviv National University of Veterinary Medicine and Biotechnology. Hedgehog, 12/3(5), 240-244. [in Ukrainian].

8. Grabarovskaya, V.O. (2016). Pratsya Volyni-2015: statystychnyy zbirnyk [Labor of Volyn-2015: Statistical Collection]. Lutsk: Main Department of Statistics in the Volyn region. [in Ukrainian].

9. Grabarovskaya, V.O. (2017). Pratsya Volyni-2016: statystychnyy zbirnyk [Labor of Volyn-2016: Statistical Collection]. Lutsk: Main Department of Statistics in the Volyn region. [in Ukrainian].

10. Grabarovskaya, V.O. (2018). Pratsya Volyni-2017: statystychnyy zbirnyk [Labor of Volyn-2017: Statistical Collection]. Lutsk: Main Department of Statistics in the Volyn region. [in Ukrainian]. 